Artikel Penelitian

\title{
Formulasi Breakfast Meal Flakes dari Tepung Suweg dan Stabilized Rice Bran Menggunakan Metode Respon Permukaan
} Formulation of Breakfast Meal Flakes Based on Suweg Flours and Stabilized Rice Bran using Response Surface Methodology

Adha Nuriana, Nur Aini*, Karseno

Program Studi IImu dan Teknologi Pangan, Fakultas Pertanian, Universitas Jenderal Soedirman, Purwokerto

*Korespondensi dengan penulis (nur.aini@unsoed.ac.id)

Artikel ini dikirim pada tanggal 20 Desember 2018 dan dinyatakan diterima tanggal 19 April 2019. Artikel ini juga dipublikasi secara online melalui https://ejournal2.undip.ac.id/index.php/jatp. Hak cipta dilindungi undang-undang. Dilarang diperbanyak untuk tujuan komersial. Diproduksi oleh Indonesian Food Technologists® (C2019

\begin{abstract}
Abstrak
Penelitian bertujuan untuk mengetahui jumlah tepung suweg dan stabilized rice bran (SRB) yang harus ditambahkan dalam formula breakfast meal flakes (BMF) yang optimal serta mengetahui karakter fisik, kimia, dan organoleptik BMF yang dihasilkan. Penelitian menggunakan metode respon permukaan dengan model Central Composit Design. Faktor yang diteliti yaitu proporsi tepung suweg dan SRB. Pembuatan BMF dilakukan dengan cara pencampuran tepung suweg (proporsi $70-85 \%$ ) dan SRB (proporsi 15-30\%) dengan bahan lainnya yaitu tapioka $10 \%$, susu skim $15 \%$, garam $1,5 \%$, margarin $5 \%$, baking powder $3 \%$, vanili $1 \%$ (seluruh persentase terhadap berat tepung suweg dan SRB) dan air $100 \mathrm{ml}$, hingga membentuk adonan, kemudian dilakukan steam blanching, dicetak dan dipanggang. Penelitian ini berhasil untuk menentukan formula optimum untuk pembuatan BMF yaitu sebesar $22,5 \%$ untuk SRB dan $77,5 \%$ untuk tepung suweg. Produk BMF dari formula terbaik ini mempunyai hardness sebesar 29,44 N, dan serat pangan, antioksidan, protein, kadar lemak, kadar air, kadar abu dan karbohidrat masing-masing sebesar 15,93, 75,10, 11,7, 9,51, 2,4, 2,16, dan 64,21\%. Warna produk akhir adalah coklat keabuan dengan tekstur yang renyah serta aroma yang netral. Rasa pada produk akhir adalah dinilai tidak pahit dengan nilai kesukaan adalah disukai panelis. Kesimpulannya, formula optimal BMF dari tepung suweg dan SRB berhasil ditentukan dengan menggunakan metode respon permukaan.
\end{abstract}

Kata kunci : antioksidan. flakes, serat pangan, suweg, stabilized rice bran

\begin{abstract}
The purpose of this research was to study the amount of suweg flour and stabilized rice bran (SRB) which must be added in the optimal breakfast meal flakes (BMF) formula and to study the physical, chemical, and organoleptic characteristics of BMF was produced. The study used Response Surface Methodology with the Central Composite Design model examined the proportion of suweg flour and SRB. Making BMF is done by mixing suweg flour (70-85\%) and SB flour (15-30\%) with other ingredients namely 10\% tapioca starch, $15 \%$ skim milk, $1.5 \%$ salt, $5 \%$ margarine, 3\% baking powder, $1 \%$ vanilla (all percentages of the weight of suweg flour and SRB), and $100 \mathrm{ml}$ of water, to form a mixture, then steam blanching, molded and baked. The best formula for BMF is the proportion of $22.5 \%$ of SRB and $77.5 \%$ of flour suweg. Breakfast meal flakes have a hardness value of $29.44 \mathrm{~N}$, dietary fiber $15.93 \%$, antioxidant of $75.97 \%$, protein content of $11.7 \%$, fat of $9.51 \%$, moisture of $2.4 \%$, ash content of $2.16 \%$, the carbohydrate content of $64.21 \%$, color of 2.3 (grayish brown), texture of 3.3 (crispy), flavor 2.5 (neutral), taste of 2.9 (not bitter), and preference 2.9 (likes). As conclusion, surface response method successfully determined the optimal BMF formula from flour suweg and SRB.
\end{abstract}

Keywords : antioxidant, flakes, dietary fiber, suweg, stabilized rice bran

\section{Pendahuluan}

Breakfast meal flakes (BMF) merupakan pangan sarapan siap santap yang popular di beberapa negara maju yang dinilai efektif dalam menurunkan indeks massa tubuh (Cho et al., 2013). Saat ini produk pangan sarapan yang ada terbuat dari serealia seperti gandum, jagung, millet maupun beras (Jeswani et al., 2015; Brennan et al., 2012). Untuk memanfaatkan sumber pangan lokal di Indonesia, pangan sarapan juga dapat dibuat dari umbi-umbian seperti umbi suweg.

Umbi suweg (Amorphophallus campanulatus) merupakan tanaman umbi-umbian yang memiliki kadar karbohidrat paling kecil namun tinggi serat dan memiliki indeks glikemik yang rendah, sehingga sangat dapat dijadikan bahan pangan fungsional. Menurut Dey et al. (2016), suweg mengandung alkaloid, tannin, flavonoid, protein dan asam amino, sterol dan terpenoid, karbohidrat, lemak dan minyak dan dapat berperan sebagai antioksidan dan antibakteri (Dey et al., 2012; Ansil et al., 2011; Khan et al., 2008). Menurut Tyas et al. (2018) umbi suweg juga menurunkan kadar gula darah pada penderita diabetes. Penelitian pengolahan umbi suweg belum banyak, beberapa produk yang diteliti dari suweg antara lain karakterisasi tepung suweg dan penggunaannya sebagai bahan pengisi nuget (Hasbullah dan Umiyati, 2017; Gumilar et al., 2011).

Tepung umbi suweg dapat menjadi alternatif bahan baku BMF, akan tetapi tepung suweg memiliki 
kadar protein rendah sehingga perlu disubstitusi dengan bahan berprotein tinggi. Rice bran atau bekatul merupakan produk samping hasil penggilingan padi yang memiliki kadar protein tinggi (10-15\%) dan dapat diaplikasikan pada produk pangan (Sharif et al., 2014; Phongthai et al., 2017). Rice bran dinilai mengandung senyawa fenolik, serta kaya akan serat pangan, protein, vitamin dan mineral serta dapat digunakan sebagai anti hipokolesterolemik dan anti aterogenik (Muntana dan Prasong, 2010; Sohail et al., 2017; Zhou et al., 2017). Hingga saat ini upaya pengembangan rice bran sebagai pangan fungsional masih terhalang beberapa kendala, antara lain kurangnya kesadaran masyarakat tentang manfaat kesehatan yang diperoleh dari mengkonsumsi rice bran, kualitas rice bran yang belum terstandar, serta banyak industri hilir yang belum tertarik mengembangkan rice bran (Bhatnagar, et al., 2014).

Selama pengolahan dan penanganan perlu dijaga kualitas rice bran agar tidak menurun. Penurunan kualitas rice bran disebabkan oleh aktivitas enzim lipase yang menyebabkan terbentuknya aroma tengik atau rancid (Liu et al., 2017) yang dapat menurunkan penerimaan konsumen. Stabilisasi rice bran (SRB) perlu dilakukan untuk menginkatifkan enzim lipase dan dihasilkan rice bran dengan aroma dan flavor yang disukai (Rafe dan Sadeghian, 2017). Berdasarkan kandungan serat, protein dan antioksidan yang dimiliki dari kedua bahan pangan tersebut dapat dijadikan rujukan untuk mendukung pengembangan produk BMF sebagai alternatif pangan sarapan.

Pangan yang diinginkan tidak hanya bernilai gizi tinggi, akan tetapi juga harus memenuhi tiga fungsi dasar yaitu sensory (warna dan penampilannya yang menarik dan citarasa yang enak), nutritional (bernilai gizi tinggi), dan physiological atau memberikan pengaruh fisiologis yang menguntungkan bagi tubuh (Liu et al., 2017; Choi dan Zhao, 2014), sehingga diperlukan penelitian mengenai formulasi terhadap proporsi tepung suweg dan SRB agar menghasilkan produk pangan fungsional yang memenuhi tiga fungsi dasar pangan fungsional. Tujuan penelitian ini adalah untuk mengetahui jumlah tepung suweg dan SRB yang harus ditambahkan dalam formula BMF yang optimal serta mengetahui karakter fisik, kimia, dan organoleptik BMF yang dihasilkan. Penelitian ini dapat memberikan informasi tentang potensi suweg sebagai bahan baku BMF sebagai pangan fungsional.

\section{Materi dan Metode \\ Materi}

Bahan yang digunakan dalam penelitian ini ialah umbi suweg yang diperoleh dari Purbalingga dan rice bran dari penggilingan beras di Purwokerto. Bahan tambahan berupa tapioka, susu skim, margarin, baking powder, garam dan vanili diperoleh dari toko bahan roti moderen di Purwokerto serta bahan untuk analisis. Peralatan yang digunakan selama penelitian antara lain peralatan untuk produksi SRB dan BMF termasuk timbangan analitik, oven, blender, ayakan ukuran 80 mesh dan cetakan. Peralatan yang digunakan diantaranya texture analyzer (Brookfield CT3 LFRA,
USA), cawan porselin, oven (Memert 854 Schwabach, Germany), desikator, neraca analitik, Soxhlet ( $\mathrm{P}$ selecta Recisterm, Germany), labu lemak (Duran, Germany), labu Kjedahl (Duran, Germany), tanur (Thermolyne Series-1000, Germany), almari asam, dan seperangkat peralatan gelas.

\section{Metode}

Penelitian dilakukan pada bulan Agustus sampai Desember tahun 2018 di Laboratorium Pengolahan Pangan dan Laboratorium Pangan Gizi, Fakultas Pertanian, serta Laboratorium Hasil Ternak Fakultas Peternakan Universitas Jenderal Soedirman Purwokerto.

Tahapan pertama yang dilakukan yaitu formulasi BMF untuk mendapatkan formula terbaik. Rancangan percobaan dalam penelitian menggunakan Respon Surface Methodogy (RSM) dengan model Central Composite Design (CCD) (Yu dan Oh, 2014). Terdapat 2 faktor yang dicoba yakni proporsi tepung suweg dengan batas bawah $70 \%$ dan batas atas $85 \%$ serta SRB dengan batas bawah $15 \%$ dan batas atas $30 \%$. Penetapan formula dilakukan menggunakan Design Expert versi 11 sehingga didapatkan 13 formula yang dicoba pada penelitian tahap pertama (Tabel 1). Tahap kedua adalah optimasi formula menggunakan data-data yang diperoleh pada tahap pertama. Berdasarkan hasil optimasi kemudian dilakukan verifikasi formula terpilih.

Tabel 1. Formula (\%) yang dicoba pada penelitian tahap pertama

\begin{tabular}{lcc}
\hline Run & SRB & Tepung suweg \\
\hline 1 & 15 & 70 \\
2 & 22,5 & 66,8934 \\
3 & 22,5 & 77,5 \\
4 & 22,5 & 77,5 \\
5 & 22,5 & 77,5 \\
6 & 11,8934 & 77,5 \\
7 & 22,5 & 77,5 \\
8 & 15 & 85 \\
9 & 22,5 & 77,5 \\
10 & 30 & 70 \\
11 & 33,1066 & 77,5 \\
12 & 22,5 & 88,1066 \\
13 & 30 & 85 \\
\hline
\end{tabular}

\section{Proses Pembuatan Tepung Suweg}

Umbi suweg dicuci kemudian dikupas dan diiris tipis dengan ketebalan $\pm 0,2 \mathrm{~cm}$. Tahap selanjutnya adalah perendaman pada larutan $\mathrm{NaCl} 5 \%$ selama 30 menit, kemudian dicuci, ditiriskan dan dikeringkan menggunakan suhu $30^{\circ} \mathrm{C}$ selama 16 jam. Umbi suweg yang telah kering selanjutnya dihancurkan dan diayak menggunakan ayakan ukuran 80 mesh. Tepung yang lolos ayakan selanjutnya disimpan dalam kontainer anaerobik (Hasbullah dan Umiyati, 2017).

\section{Proses Stabilisasi Rice Bran}

Proses stabilisasi rice bran mengacu pada penelitian Patil et al. (2016). Rice bran dibersihkan kemudian dilakukan stabilisasi menggunakan microwave oven pada suhu $110^{\circ} \mathrm{C}$ selama 3 menit. 


\section{Pembuatan BMF}

Tepung suweg dan bekatul dengan perbandingan tertentu dicampur dengan bahan lain. Bahan lain yang ditambahkan meliputi tapioka $10 \%$, susu skim $15 \%$, garam $1,5 \%$, margarin $5 \%$, baking powder $3 \%$, vanili $1 \%$ (seluruh persentase terhadap berat tepung suweg dan bekatul) dan air $100 \mathrm{ml}$. Seluruh bahan dicampur rata sampai terbentuk adonan. Selanjutnya dilakukan steam blanching adonan selama 25 menit. Adonan kemudian ditipiskan serta dicetak dengan ketebalan $\pm 3 \mathrm{~mm}$. Tahap berikutnya adalah pemanggangan adonan pada $120^{\circ} \mathrm{C}$ selama 25 menit sehingga BMF matang (Sukasih dan Setyadjit, 2012).

\section{Prosedur analisa}

Variabel yang diamati meliputi hardness menggunakan texture analyzer, serat pangan dengan menggunakan metode enzimatik (AOAC, 2005), antioksidan dengan menggunakan metode DPPH (Joo dan Choi, 2012), protein dengan total menggunakan metode Kjeldahl (AOAC, 2005), kadar air dengan menggunakan metode gravimetri (AOAC, 2005), kadar abu dengan menggunakan metode gravimetri (AOAC, 2005), kadar lemak dengan menggunakan Soxhlet (AOAC, 2005), dan karbohidrat (dihitung dengan metode by difference).

Uji sensori dilakukan sesuai dengan metode peneliti sebelumnya (Pradeep et al., 2014), yang dilakukan untuk menentukan tingkat penerimaan dari warna, tekstur, aroma dan kesukaan BMF. Uji kesukaan dilakukan pada BMF yang diseduh menggunakan susu (siap dikonsumsi). Pengujian dilakukan oleh 25 orang panelis semi terlatih yang sebelumnya diberi pengarahan sehingga mereka paham mengenai parameter yang akan diuji. Pengujian menggunakan metode skoring menggunakan skor pada range antara 1 (skor tingkat terendah) sampai 5 (skor tingkat tertinggi). Parameter tersebut adalah warna $(1=a b u-a b u, 2=$ coklat keabuan, $3=$ coklat, $4=$ sangat coklat, $5=$ sangat coklat sekali), tekstur ( $1=$ tidak renyah, $2=$ agak renyah, $3=$ renyah, $4=$ sangat renyah, $5=$ sangat renyah sekali), aroma rice bran (1= tidak terasa, $2=$ agak terasa, $3=$ terasa, $4=$ sangat terasa, $5=$ sangat terasa sekali), rasa ( $1=$ tidak pahit, $2=$ agak pahit, $3=$ pahit, $4=$ sangat pahit, $5=$ sangat pahit sekali), dan kesukaan ( $1=$ tidak suka, $2=$ agak suka, $3=$ suka, $4=$ sangat suka, $5=$ sangat suka sekali).

\section{Analisis Data}

Data formula optimasi berdasarkan rancangan CCD dengan respon maksimum yang didapatkan kemudian dianalisis dengan Respone Surface Methodology software design expert V.11.

\section{Hasil dan Pembahasan}

Analisis Total Protein

Interaksi antara SRB dan tepung suweg berpengaruh nyata terhadap kadar protein total protein total flakes dengan model kuadratik pada tingkat signifikansi 0,0001. Kadar protein flakes antara 8,51$13,07 \%$ (Figur 1). Semakin banyak rice bran yang ditambahkan, kadar protein flakes semakin meningkat. Hal ini disebabkan rice bran memiliki kadar protein tinggi yaitu 27\% (Fabian and Ju, 2011), lebih tinggi daripada tepung suweg yaitu $2,78-3,91 \%$ (Hasbullah dan Umiyati, 2017)

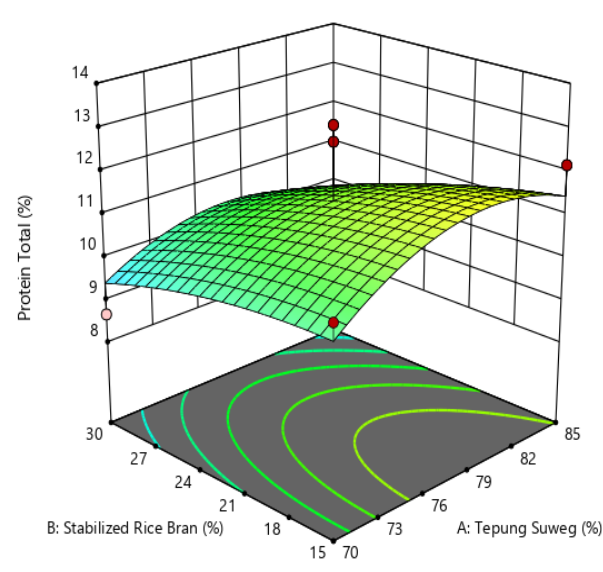

Figur 1. Respon kadar protein total BMF pada variasi proporsi tepung suweg dan SRB

Peningkatan kadar protein pada BMF dengan meningkatnya jumlah rice bran yang ditambahkan ini sejalan dengan hasil penelitian Al-Okbi et al. (2014) yang menyatakan bahwa semakin banyak rice bran yang ditambahkan pada pembuatan flakes dan tortila jagung dapat meningkatkan kadar proteinnya. Yousaf et al. (2013) juga menyatakan bahwa penambahan rice bran pada pembuatan biskuit dari tepung terigu dapat meningkatkan kadar protein dibandingkan biskuit tanpa penambahan rice bran.

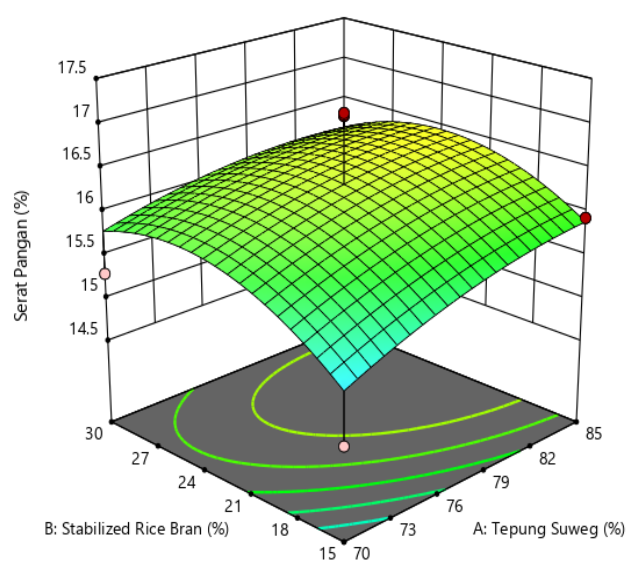

Figur 2. Respon kadar serat pangan BMF pada variasi proporsi tepung suweg dan SRB

Proporsi SRB dan tepung suweg tidak berpengaruh signifikan pada kadar serat pangan BMF (Tabel 2). Kadar serat pangan BMF ini antara 14,55$17,12 \%$ (Figur 2). Kadar serat pangan ini lebih besar daripada serat pangan flakes dari talas, pisang dan kacang hijau hasil penelitian Sukasih dan Setyadjit (2012) yaitu $8,07 \%$. Tepung suweg memiliki kadar serat pangan 15,09\% (Ansil et al., 2011), sedangkan rice bran 25,3 g (Nagendra et al., 2011). Kadar serat pangan bahan flakes ini lebih tinggi daripada bahan flakes yang 
diteliti Sukasih dan Setyadjit (2012) yaitu masing-masing 1,$4 ; 15,5$; dan $7,5 \%$ sehingga kadar serat pangan BMF hasil penelitian ini lebih tinggi, Jenis serat yang terdapat pada rice bran adalah selulosa yang tidak dicerna dalam pencernaan (Gul et al., 2015). Selulosa menyediakan bahan pengenyang dan bahan kasar pada pangan yang membantu memelihara daya gerak dan kesehatan saluran pencernaan (Khoury et al., 2018).

Tabel 2. Hasil pengujian ANOVA Respon Surface Quadratic model pada variabel yang diamati

\begin{tabular}{lccl}
\hline Variabel & Nilai $\mathrm{F}$ & Nilai P & Signifikansi \\
\hline Hardness & 1,12 & 0,4297 & Tidak signifikan \\
Antioksidan & 7,48 & 0,0099 & Signifikan \\
Serat pangan & 2,29 & 0,1554 & Tidak signifikan \\
Protein & 44,07 & 0,0001 & Signifikan \\
Warna & 5,20 & 0,0261 & Signifikan \\
Tekstur & 0,9146 & 0,5224 & Tidak signifikan \\
Aroma & 0,3786 & 0,8488 & Tidak signifikan \\
Rasa & 4,10 & 0,0464 & Signifikan \\
Kesukaan & 1,06 & 0,4545 & Tidak signifikan \\
\hline
\end{tabular}

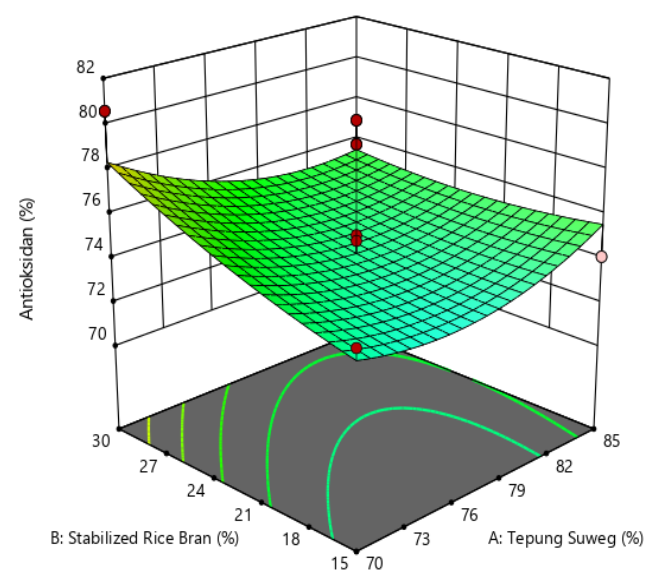

Figur 3. Respon antioksidan BMF pada variasi proporsi tepung suweg dan SRB

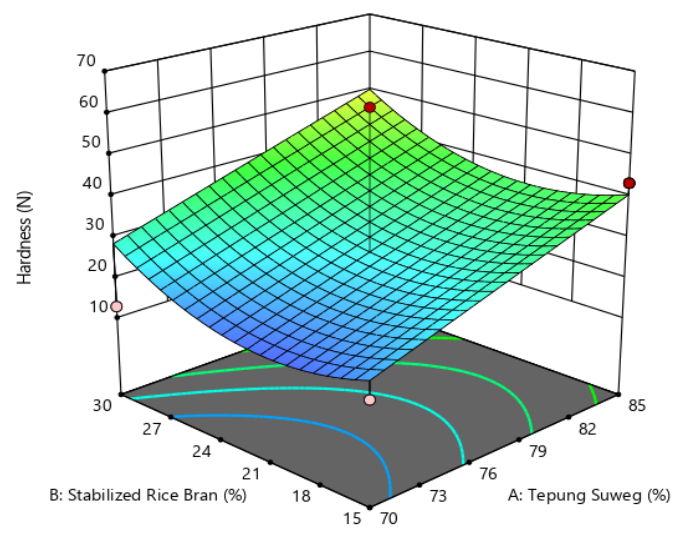

Figur 4. Respon hardness BMF pada variasi proporsi tepung suweg dan SRB

Aktivitas antioksidan BMF ini antara 70,53$80,59 \%$ (Figur 3). Semakin tinggi kadar tepung suweg, semakin besar aktivitas antioksidannya karena suweg memiliki aktivitas antioksidan tinggi, yaitu sebesar
77,13\% (Firman et al., 2016). Rice bran juga sebenarnya memiliki aktivitas antioksidan tinggi (Hartati et al., 2015; Arab et al., 2011), akan tetapi pada penelitian ini peningkatan jumlah SRB tidak terlihat pada peningkatan aktivitas antioksidan.

Komponen yang berperan sebagai antioksidan pada rice bran terutama adalah komponen polifenol, misalnya phenolic acid, anthocyanin, dan proanthocyanidin (Pang et al., 2018). Komponen yang dapat berperan sebagai antioksidan pada suweg adalah flavonoid, saponin dan polifenol (Firman et al., 2016).

Proporsi tepung suweg dan SRB tidak berpengaruh nyata terhadap hardness BMF seperti dapat dilihat pada Tabel 2. Hardness BMF ini adalah 12,73-64,14 N (Figur 4). Menurut Paula and Conti-silva (2014), nilai hardness berbanding terbalik dengan kerenyahan, yang berarti semakin tinggi nilai hardness, berarti produk semakin tidak renyah, dan sebaliknya. Hardness BMF dari tepung suweg ini memiliki kekerasan yang sangat bervariasi, berbeda dengan pernyataan Mahmudah et al. (2015) yang menyatakan bahwa nilai kekerasan flakes pisang kepok bersubtitusi pati garut berkisar 27,07-37,10 N.

Protein dapat meningkatkan kemampuan gelasi sehingga dapat membentuk fleksibilitas dan membentuk jaringan dengan ikatan silang (Tunick et al., 2013). Pada produk flakes berbasis tepung suweg dengan penambahan $S R B$, keduanya memiliki kandungan bahan seperti serat dan protein dengan jumlah yang berbeda namun kandungan bahan tersebut tidak berpengaruh secara nyata terhadap kontribusi tekstur flakes.

\section{Analisis Sifat Sensori}

Interaksi antara konsentrasi tepung suweg dan SRB berpengaruh nyata terhadap warna BMF dengan model kuadratik pada signifikansi 0,0261 (Tabel 2). Berdasarkan Figur 5, BMF memiliki warna antara 1,5 (coklat keabuan) sampai 2,7 (coklat). Warna coklat keabuan dikarenakan tepung suweg memiliki warna putih abu-abu sebelum diolah menjadi flakes berbeda dengan tepung biasa yang berwarna putih. Menurut Hasbullah dan Umiyati (2017), sifat fisik tepung suweg antara lain halus, berwarna putih keabu-abuan, atau kecoklatan-coklatan dikarenakan adanya reaksi browning enzimatis pada saat pengupasan yang mana terjadinya interaksi antara enzim polifenol oksidase dengan oksigen sehingga warna tepung suweg kurang putih dibandingkan tepung sukun, tapioka, ataupun terigu. Selain warna bahan awal adanya perubahan warna pada flakes dipengaruhi juga oleh proses pengovenan. Perubahan warna terjadi karena adanya reaksi maillard, dimana gula akan bereaksi dengan protein pada suhu pengovenan sehingga menghasilkan warna coklat pada permukaan produk (Oliver et al., 2006).

Interaksi antara tepung suweg dan SRB tidak berpengaruh terhadap terhadap sifat sensoris tekstur (Tabel 2). Nilai tekstur BMF berkisar antara 2,25 (agak renyah) sampai 3,25 (renyah) (Figur 6). Hasil pengukuran tekstur secara sensori yang tidak berbeda 
nyata ini sejalan dengan hasil pengukuran tekstur secara subyektif menggunakan texture analyzer pada Figur 4.

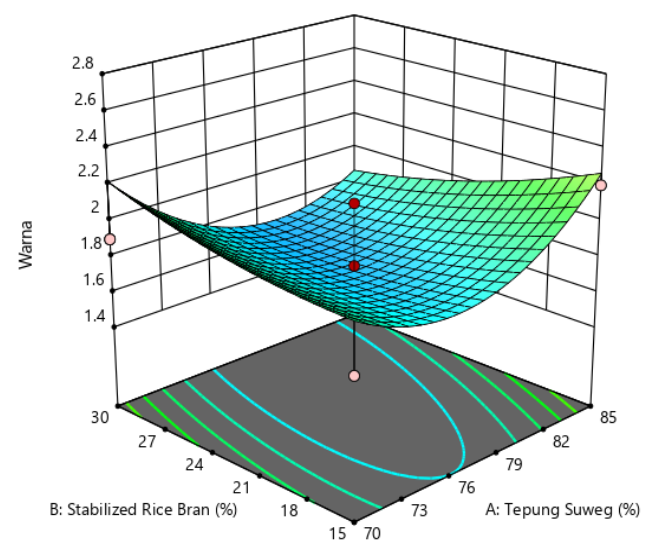

Figur 5. Respon sifat sensori warna BMF pada variasi proporsi tepung suweg dan SRB

Tekstur pada suatu produk pangan dipengaruhi oleh perbandingan antara amilosa dan amilopektin. Menurut Lianah et al. (2018), umbi suweg memiliki kadar amilopektin tinggi yaitu $75,5 \%$ dan amilosa $24,5 \%$. Komposisi amilosa dan amilopektin ini menghasilkan BMF dengan tekstur renyah. Penambahan tepung tapioka dengan jumlah yang sama untuk setiap perlakuan menimbulkan pengaruh proporsi dari umbi suweg dan bekatul tidak nyata terhadap tekstur flakes.

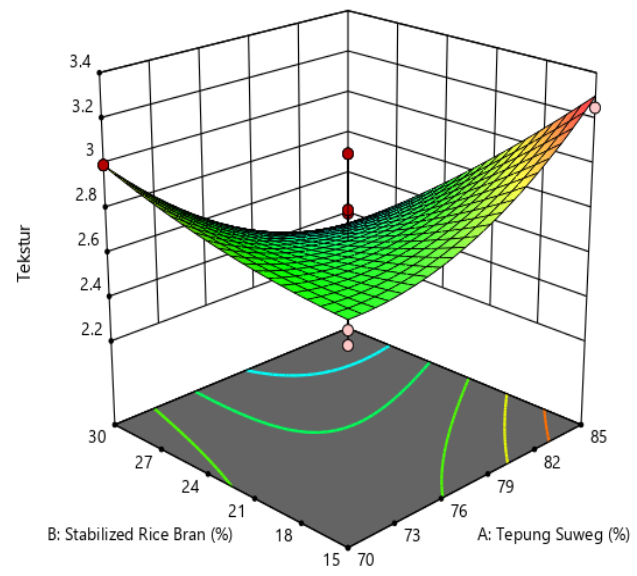

Figur 6. Respon sifat sensori tekstur BMF pada variasi proporsi tepung suweg dan SRB

Interaksi antara komposisi tepung suweg dan SRB tidak memberikan pengaruh nyata terhadap aroma $B M F$ (Tabel 2). Hal ini dikarenakan rice bran yang digunakan sudah mengalami proses stabilisasi sehingga aktivitas enzim lipase penyebab ketengikan atau aroma khas rice bran berkurang karena dihambat oleh proses stabilisasi.

Interaksi antara proporsi tepung suweg dan SRB tidak berpengaruh nyata terhadap kesukaan $B M F$ (Tabel 2). Nilai kesukaan BMF antara 1,85 (agak suka) sampai 3,8 (suka) (Figur 8). Kesukaan dipengaruhi oleh beberapa faktor antara lain: warna, rasa, aroma, dan penampilan menarik serta bernilai gizi tinggi dan memberikan keuntungan bagi manusia (Gracia, 2016).
Kesukaan sangat dipengaruhi oleh subyektifitas konsumen dan menentukan penerimaan konsumen terhadap produk makanan.

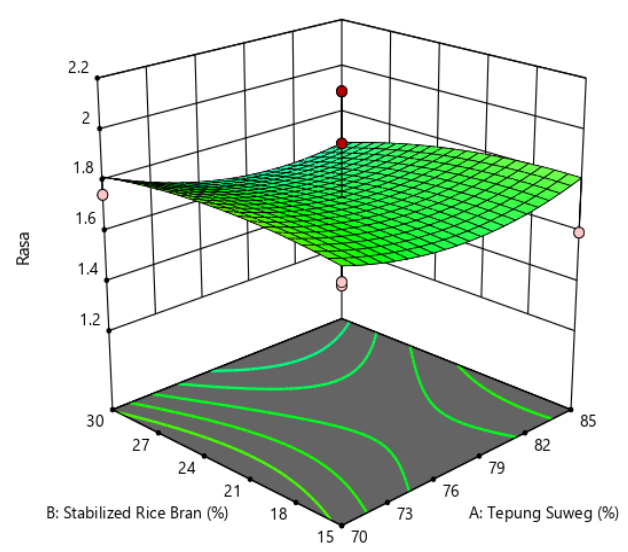

Figur 7. Respon sifat sensori rasa BMF pada variasi proporsi tepung suweg dan SRB

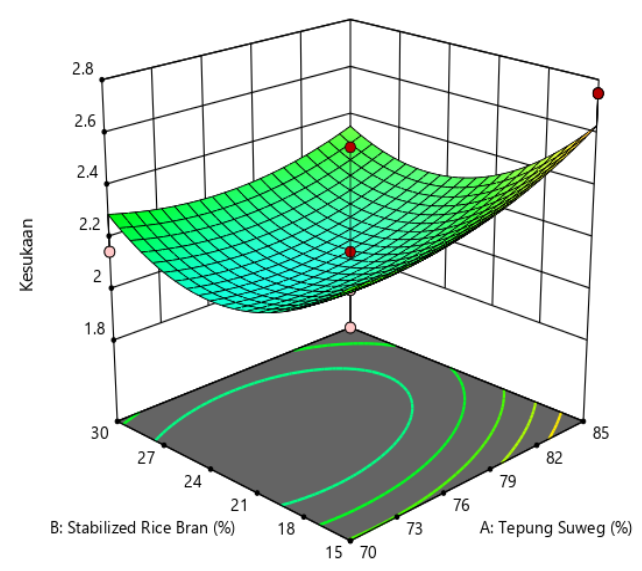

Figur 8. Respon sifat sensori kesukaan BMF pada variasi proporsi tepung suweg dan SRB

\section{Verifikasi Formula Optimum}

Formula optimum yang disarankan untuk BMF adalah dengan komposisi SRB $22,5 \%$ dan tepung suweg $77,5 \%$. Komposisi formula optimum yang disarankan masih didalam range komposisi yang diuji, walaupun nilai desirabilitynya tidak tinggi, yaitu 0,593. Keunggulan penggunaan metode Response Surface Method adalah dapat memprediksi formula optimum variabel respon yang diuji pada range tertentu. Nilai hasil pengujian formula tersebut seperti terlihat pada Tabel 3 adalah hardness $29,44 \mathrm{~N}$, serat pangan $15,55 \%$ antioksidan $74,78 \%$, kadar protein $10,970 \%$, dengan sifat sensori warna 1,8 (coklat keabuan), tekstur 2,6 (renyah), aroma 2 (agak terasa), rasa 2,9 (netral), dan kesukaan 2,3 (agak suka).

Nilai desirability yang dihasilkan sangat dipengaruhi oleh kompleksitas komponen, kisaran yang digunakan dalam komponen, jumlah komponen dan respon, serta target yang ingin dicapai dalam memperoleh formula optimum. Menurut Rawson and Vca (2015), jumlah komponen faktor dan respon juga turut memengaruhi nilai desirability formula optimum. 
Semakin banyak jumlah komponen dan respon, maka semakin sulit untuk mencapai keadaan optimum sehingga desirability yang dihasilkan kemungkinan rendah.

Seluruh data aktual dari pengamatan dan pengukuran yang dilakukan berada pada selang nilai yang diprediksikan (Tabel 3). Hal ini menunjukkan bahwa karakteristik flakes formula optimum sesuai dengan yang diinginkan. PI ditujukan untuk mengetahui batas atas sebagai nilai optimis dan batas bawah sebagai nilai pesimis pada setiap titik peramalan (Neill et al., 2018). Hasil penelitian menunjukkan bahwa flakes dengan formula optimum memiliki warna coklat keabuan, tekstur renyah, aroma agak terasa), rasa netral dan kesukaan agak suka.

$B M F$ berbasis tepung suweg dengan penambahan SRB telah memenuhi standar mutu yang diterapkan oleh Badan Standarisasi Nasional (2000) pada SNI 01-4270-1996 (Tabel 4). Hasil penelitian menunjukkan bahwa flakes dengan formula optimum memiliki kadar air 2,4\%, masih memenuhi syarat menurut Badan Standarisasi Nasional (2000) dalam SNI 01-4270-1996 yaitu maksimal 3. Kadar air ini lebih rendah dibandingkan flakes dari pati garut dan tepung ikan yaitu 4\% (Amalia dan Klara, 2013).

Kadar abu BMF formula optimum sebesar 2,16\%, memenuhi Badan Standarisasi Nasional (2000) SNI yaitu maksimum 4\%. Kadar abu ini lebih rendah daripada kadar abu flake pati garut oleh Amalia dan Klara (2013) yaitu sebesar 5,9\%. Rice bran merupakan sumber mineral, yaitu 8,3\% (Hartati et al., 2015), akan tetapi penambahannya tidak mengakibatkan kadar mineral BMF ini menjadi tinggi.

Kadar protein BMF ini sebesar $11,7 \%$, masuk dalam persyaratan SNI 01-4270-1996 yaitu minimal 5\% (Tabel 2). Suweg memiliki kadar protein rendah yaitu hanya $1 \%$, akan tetapi penambahan rice bran yang memiliki kadar protein $16,5 \%$ mampu menghasilkan BMF dengan kadar protein tinggi. BMF ini memiliki kadar protein lebih tinggi daripada flakes dari pati garut, yaitu 7,6\% (Amalia dan Klara, 2013).
BMF ini memiliki kadar lemak 9,51\%. Rice bran memiliki kadar lemak tinggi yaitu $21,3 \%$ sehingga penambahannya pada pembuatan BMF akan menigkatkan kadar lemaknya. Meskipun kadar lemaknya tinggi, akan tetapi lemak pada rice bran didominasi asam lemak tak jenuh yang baik untuk kesehatan.

Kadar serat pangan pada BMF ini sebesar $15,94 \%$. Jumlah serat pangan yang harus dikonsumsi adalah 20-35 g/hari (Lianah, 2018). BMF ini dapat diklaim sebagai pangan serat tinggi karena memiliki $75 \%$ dari kebutuhan serat pangan. Menurut Karmini dan Briawan (2004), suatu produk pangan diklaim sebagai produk pangan tinggi suatu zat gizi dengan persyaratan memenuhi kontribusi 20\% Acuan Label Gizi (ALG) per 100 gram dalam bentuk padat atau 10\% ALG per 100 kkal atau 20\% ALG per sajian. Penambahan serat pangan konvensional pada produk pangan mempengaruhi kecilnya daya terima konsumen akibat kualitas organoleptik yang rendah seperti tekstur yang kasar dan dry mouth-feel. Kadar karbohidrat flakes sebesar $64,21 \%$, masih memenuhi persyaratan Badan Standarisasi Nasional (2000) dalam SNI 01-4270-1996 yaitu minimal $60 \%$.

\section{Kesimpulan}

Jumlah SRB dan tepung suweg untuk menghasilkan formula yang optimum dalam hal karakter fisik, kimia, dan organoleptiknya, diperlukan proporsi sebesar $22,5: 77,5 \%$.

\section{Ucapan Terima Kasih}

Peneliti menyampaikan penghargaan yang tinggi dan terima kasih kepada PT Indofood Sukses Makmur Tbk yang telah membiayai penelitian ini melalui program Indofood Riset Nugraha 2018.

\section{Daftar Pustaka}

Al-Okbi, S.Y., Hussein, A.M.S., Hamed, I.M., Mohamed, D.A., Helal, A.M. 2014. Chemical, rheological, sensorial and functional properties of gelatinized

Tabel 3. Hasil verifikasi formula optimum dibandingkan dengan prediksi

\begin{tabular}{lcccc}
\hline Respon & Data aktual & \multicolumn{2}{c}{ Nilai prediksi } & Verifikasi \\
\cline { 3 - 4 } & hasil pengujian & R Rendah & R Tinggi & \\
\hline Hardness $(\mathrm{N})$ & 29,44 & $-18,16$ & 78,22 & Sesuai \\
Serat pangan (\%) & 15,94 & 14,085 & 17,008 & Sesuai \\
Antioksidan (\%) & 75,097 & 70,8373 & 78,7313 & Sesuai \\
Protein total (\%) & 11,07 & 10,08 & 11,85 & Sesuai \\
Warna & 2,3 & 1,27 & 2,32 & Sesuai \\
Tekstur & 3,3 & 1,79 & 3,42 & Sesuai \\
Aroma & 2,5 & 1,49 & 2,52 & Sesuai \\
Rasa & 2,9 & 1,27 & 2,08 & Sesuai \\
Kesukaan & 2.9 & 1,64 & 2,97 & Sesuai \\
\hline
\end{tabular}

Tabel 4. Hasil pengujian kandungan kimia flakes terhadap kesesuaian standar mutu breakfast cereal

\begin{tabular}{clcc}
\hline Vo & Komponen & BMF tepung suweg + SRB & SNI 01-4270-1996 \\
\hline 1. & Air & $2,4 \%(\mathrm{~b} / \mathrm{b})$ & Maks 3,0 \% (b/b) \\
2. & Abu & $2,16 \%(\mathrm{~b} / \mathrm{b})$ & Maks $4,0 \%(\mathrm{~b} / \mathrm{b})$ \\
3. & Protein & $11,7 \%(\mathrm{~b} / \mathrm{b})$ & Min $5,0 \%(\mathrm{~b} / \mathrm{b})$ \\
4. & Lemak & $9,51 \%(\mathrm{~b} / \mathrm{b})$ & tidak ada \\
5. & Karbohidrat & $64,21 \%(\mathrm{~b} / \mathrm{b})$ & Min $60 \%(\mathrm{~b} / \mathrm{b})$ \\
6. & Serat pangan & $15,94 \%$ & tidak ada \\
\hline
\end{tabular}


corn- rice bran flour composite corn flakes and tortilla chips. Journal of Food Processing and Preservation 38(1):83-89. DOI:10.1111/j.17454549.2012.00747.x.

Amalia, F., Klara, K. 2013. Formulasi flakes pati garut dan tepung ikan lele dumbo (Clarias gariepinus) sebagai pangan kaya energi protein dan mineral untuk lansia. Jurnal Gizi dan Pangan 8(12):137144. DOI:10.25182/jgp.2013.8.2.137-144.

Ansil, P.N., Nitha, A., Prabha, S.P., Wills, P.J., Jazaira, V., Latha, M.S. 2011. Protective effect of Amorphophallus campanulatus (Roxb.) Blume tuber against thioacetamide induced oxidative stress in rats. Asian Pacific Journal of Tropical Medicine 4(11):870-877. DOI:10.1016/S19957645(11)60211-3.

AOAC. 2005. Official Methods of Analysis of the Association of Official Agricultural Chemists International. Journal of the Association of Official Agricultural Chemists 41:12.

Arab, F., Alemzadeh, I., Maghsoudi, V. 2011. Determination of antioxidant component and activity of rice bran extract. Scientia Iranica 18(6):1402-1406. DOI:10.1016/J.SCIENT.2011. 09.014

Badan Standarisasi Nasional. 2000. Syarat Mutu Sereal (SNI 01-4270-1996). Badan Standarisasi Nasional. Jakarta.

Bhatnagar, A.S., Prabhakar, D.S., Kumar, P.K., Rajan, R.G., Krishna, A.G. 2014. Processing of commercial rice bran for the production of fat and nutraceutical rich rice brokens, rice germ and pure bran. LWT - Food Science and Technology 58(1):306-311. DOI:10.1016/j.Iwt.2014.03.011.

Brennan, M.A., Menard, C., Roudaut, G., Brennan, C.S. 2012. Amaranth, millet and buckwheat flours affect the physical properties of extruded breakfast cereals and modulates their potential glycaemic impact. Starch - Stärke 64(5):392-398. DOI:10.1002/star.201100150.

Cho, S., Dietrich, M., Brown, C.J.P., Clark, C.A., Block, G. 2013. The effect of breakfast type on total daily energy intake and body mass index: Results from the third National Health and Nutrition Examination Survey (NHANES III). Journal of the American College of Nutrition 22(4):296-302. DOI:10.1080/07315724.2003.10719307.

Choi, J., Zhao, J. 2014. Consumers' behaviors when eating out. British Food Journal 116(3):494-509. DOI:10.1108/BFJ-06-2012-0136.

Dey, Y.N., Mahor, S., Kumar, D., Wanjari, M., Gaidhani, S., Jadhav, A. 2016. Gastrokinetic activity of Amorphophallus paeoniifolius tuber in rats. Journal of Intercultural Ethnopharmacology 5(1):36-42. DOI:10.5455/jice.20151211063819.

Dey, Y.N., Ota, S., Srikanth, N., Jamal, M., Wanjari, M. 2012. A phytopharmacological review on an important medicinal plant - Amorphophallus paeoniifolius. Ayu 33(1): 27-32. DOI:10.4103/0974-8520.100303.

Fabian, C., Ju, Y.H. 2011. A review on rice bran protein: its properties and extraction methods. Critical Reviews in Food Science and Nutrition 51(9):816827. DOI:10.1080/10408398.2010.482678.

Firman, D., Nurhaeni, N., Ridhay, A. 2016. Aktivitas antioksidan ekstrak umbi suweg (Amorphophallus paeoniifolius) dari berbagai tingkat polaritas. Jurnal Kovalen 2:61-69. DOI:10.22487/j24775398.2016. v2.i1.6048.

Gracia, A. 2016. Assessing projection bias in consumers food preferences. PLoS ONE 1:1-12. DOI:10.1371/journal.pone.0146308.

Gul, K., Yousuf, B., Singh, A.K., Singh, P., Wani, A.A. 2015. Rice bran: nutritional values and its emerging potential for development of functional food-A review. Bioactive Carbohydrates and Dietary Fibre 6(1):24-30. DOI:10.1016/J.BCDF.2015.06.002.

Gumilar, J., Rachmawan, O., Nurdyanti, W. 2011. Kualitas fisikokimia naget ayam yang menggunakan filer tepung suweg (Amorphophallus campanulatus B1). Jurnal IImu Ternak 11(1): 1-5. DOI:10.24198/jit.v11i1.393.

Hartati, S., Marsono, Y., Suparmo, Santoso, U. 2015. Komposisi Kimia Serta Aktivitas Antioksidan Ekstrak Hidrofilik Bekatul Beberapa Varietas Padi. Agritech 35(1):35-42. DOI:10.22146/agritech.9417

Hasbullah, U. H., Umiyati, R. 2017. Perbedaan sifat fisik kimia dan sensoris tepung umbi suweg (Amorphophallus campamulatus $\mathrm{BI}$ ) pada fase dorman dan vegetatif. Planta Tropika: Jurnal Agrosains 5(2):70-78. DOI:10.18196/pt.2017.066. 70-78.

Huang, Y.P., Lai, H.M. 2016. Bioactive compounds and antioxidative activity of colored rice bran. Journal of Food and Drug Analysis 24(3):564-574. DOI:10.1016/j.jfda.2016.01.004.

Jeswani, H.K., Burkinshaw, R., Azapagic, A. 2015. Environmental sustainability issues in the foodenergy-water nexus: breakfast cereals and snacks. Sustainable Production and Consumption 2:17-28. DOI:10.1016/j.spc.2015.08.001.

Joo, S.Y., Choi, H.Y. 2012. Antioxidant activity and quality characteristics of black rice bran cookies. Journal of the Korean Society of Food Science and Nutrition 41(2):182-191. DOI:10.3746/jkfn.2012. 41.2.182.

Karmini, M., Briawan, D. 2004. Acuan label gizi, ketahanan pangan dan gizi di era otonomi daerah dan globalisasi. In Prosiding Widyakarta Nasional Pangan dan Gizi VIII.

Khan, A., Rahman, M., Islam, M.S. 2008. Antibacterial, antifungal and cytotoxic activities of amblyone isolated from Amorphophallus campanulatus. Indian Journal of Pharmacology 40(1):41-44. DOI:10.4103/0253-7613.40489.

Khoury, D.E., Balfour-ducharme, S., Joye, I.J. 2018. A review on the gluten-free diet: technological and nutritional challenges. Nutrients 10:1-27. DOI:10.3390/nu10101410.

Lianah, L., Tyas, D.A. Armanda, D.T., Setyawati, S.M. 2018. Aplikasi umbi suweg (Amorphopallus 
companulatus) sebagai alternatif penurun gula darah pada penderita Diabetes Mellitus. Al Hayat: Journal of Biology and Applied Biology 1(1):1-12. DOI:10.21580/ah.v1i1.2666.g1675.

Liu, Y.Q., Strappe, P., Shang, W.T., Zhou, Z.K. 2017. Functional peptides derived from rice bran proteins. Critical Reviews in Food Science and Nutrition 8:18. DOI:10.1080/10408398.2017.1374923.

Mahmudah, N., Amanto, B.S., Widowati, E. 2015. Karakteristik fisik, kimia dan sensoris flakes pisang Kepok Samarinda (Musa paradisiaca balbisiana) dengan Substitusi Pati Garut. Jurnal Teknologi Hasil Pertanian 5(2):25-33. DOI:10.3975/cagsb. 2015.05.08.

Muntana, N., Prasong, S. 2010. Study on total phenolic contents and their antioxidant activities of Thai white, red and black rice bran extracts. Pakistan Journal of Biological Sciences 13(4):170-174. DOI:10.3923/pjbs.2010.170.174.

Nagendra, P.M.N., Sanjay, K.R., Shravya, K.M., Vismaya, M.N., Nanjunda, S.S. 2011. Health Benefits of Rice Bran - A Review. Journal of Nutrition \& Food Sciences 01(03):1000108. DOI:10.4172/2155-9600.1000108.

Neill, C.M.O., Cruz-romero, M.C., Du, G., Kerry, J.P. 2018. The application of response surface methodology for the development of sensory accepted low-salt cooked ham using high pressure processing and a mix of organic acids. Innovative Food Science and Emerging Technologies 45:401411. DOI:10.1016/j.ifset.2017.12.009.

Nontasan, S., Moongngarm, A., Deeseenthum, S. 2012. Application of functional colorant prepared from black rice bran in yogurt. APCBEE Procedi 2:6267. DOI:10.1016/j.apcbee.2012.06.012.

Oliver, C.M., Melton, L.D., Stanley, R.A. 2006. Creating proteins with novel functionality via the Maillard Reaction: A review. Critical Reviews in Food Science and Nutrition 46(4):337-350. DOI:10.1080/10408690590957250.

Pang, Y., Ahmed, S., Xu, Y., Beta, T., Zhu, Z., Shao, Y., Bao, J. 2018. Bound phenolic compounds and antioxidant properties of whole grain and bran of white, red and black rice. Food Chemistry 240:212221. DOI:10.1016/j.foodchem.2017.07.095.

Patil, S.S., Kar, A., Mohapatra, D. 2016. Stabilization of rice bran using microwave: Process optimization and storage studies. Food and Bioproducts Processing 99: 204-211. DOI:10.1016/j.fbp.2016. 05.002.

Paula, A.M., Conti-silva, A.C. 2014. Texture profile and correlation between sensory and instrumental analyses on extruded snacks. Journal of Food Engineering 121:9-14. DOI:10.1016/j.jfoodeng. 2013.08.007.

Phongthai, S., Homthawornchoo, W., Rawdkuen, S. 2017. Preparation, properties and application of rice bran protein: A review. International Food Research Journal 24(1):25-34. DOI:10.1067/mmt. 2002.123165.
Pradeep, P. M., Dharmaraj, U., Sathyendra Rao, B. V., Senthil, A., Vijayalakshmi, N. S., Malleshi, N. G., Singh, V. 2014. Formulation and nutritional evaluation of multigrain ready-to-eat snack mix from minor cereals. Journal of Food Science and Technology 51(12):3812-3820. DOI:10.1007/ s13197-013-0949-3.

Rafe, A., Sadeghian, A. 2017. Stabilization of Tarom and Domesiah cultivars rice bran: Physicochemical, functional and nutritional properties. Journal of Cereal Science 74:64-71. DOI:10.1016/j.jcs.2017.01.019.

Rawson, A., Vca, K. 2015. Ultrasound assisted extraction of oil from rice bran: A response surface methodology approach. Journal Food Process Technology 6(6):454. DOI:10.4172/21577110.1000454.

Sharif, M.K., Butt, M.S., Anjum, F.M., Khan, S.H. 2014. Rice bran: A novel functional ingredient. Critical Reviews in Food Science and Nutrition 54(6):807816. DOI:10.1080/10408398.2011.608586.

Sohail, M., Rakha, A., Butt, M.S., Iqbal, M.J., Rashid, S. 2017. Rice bran nutraceutics: A comprehensive review. Critical Reviews in Food Science and Nutrition 57(17):3771-3780. DOI:10.1080/ 10408398.2016.1164120.

Sukasih, E., \& Setyadjit. 2012. Formulasi pembuatan flake berbasis talas untuk makanan sarapan (breakfast meal) energi tinggi dengan metode oven. Jurnal Pascapanen 9(2):70-76. DOI:10.21082/jpasca.v9n2.2012.70-76.

Tunick, M.H., Onwulata, C.I., Thomas, A.E., Phillips, J.G., Mukhopadhyay, S., Sheen, S., Cooke, P.H. 2013. Critical evaluation of crispy and crunchy textures: A review. International Journal of Food Properties 16:949-963. DOI:10.1080/ 10942912.2011 .573116$.

Tyas, D.A., Armanda, D.T., Setyawati, S.M. 2018. Aplikasi Umbi Suweg (Amorphophallus campanulatus ) sebagai alternatif penurun gula darah pada penderita diabetes mellitus. Al Hayat: Journal of Biology and Applied Biology 1(1):1-12. DOI:10.21580/ah.v1i1.2666.

Yousaf, A.L.I.A., Ahmed, A., Ahmad, A., Hameed, T., Randhawa, M.A., Hayat, I., Khalid, N. 2013. Nutritional and functional evaluation of wheat flour cookies supplemented with gram flour. International Journal of Food Science and Nutrition 64:63-68. DOI:10.3109/09637486.2012.694851.

Yu, H.H., Oh, J.C. 2014. Optimization of cookie preparation by addition of polygonum multiflorum radix powder using response surface methodology. The Korean Journal of Food And Nutrition 27(4):539-550. DOI:10.9799/ksfan.2014.27.4.539.

Zhou, L., Zhang, Y., Zhao, C., Lin, H., Wang, Z., Wu, F. 2017. Structural and functional properties of rice bran protein oxidized by peroxyl radicals. International Journal of Food Properties 20:14561467. DOI:10.1080/10942912.2017.1352596. 